\title{
STUDI TENTANG METODE MENGAJAR
}

Dalam pencapaian suatu tujuan mengajar harus menggunakan cara atau metode yang tepat. Dalam bahagian ini penulis akan membahas tentang metode mengajar tersebut.

\section{Pengertian Metode Mengajar}

Menurut Peter Salim dan Yenni Salim "Metode adalah cara yang teratur dan berfikir baik-baik untuk mencapai maksud (dalam ilmu pengetahuan); cara kerja yang bersistem untuk memudahkan pelaksanaan suatu kegiatan guna mencapai tujuan yang ditentukan."[1] Lanjut Daniel Nuhamara mengatakan "Metode adalah sebuah aspek yang lebih bersifat praktis"[2]. Sedangkan E.G Homrighausen dan I. H Enklaar mengatakan "Dalam PAK metode adalah suatu pelayanan, suatu pekerjaan yang aktif, yang kita lakukan bagi Firman Tuhan dan bagi sesama manusia, supaya kedua pihak tersebut bertemu satu sama lain." [3] Jadi metode adalah suatu cara bersistem yang bersifat praktis untuk mencapai tujuan yang hendak dicapai.

Mengajar bukanlah hal yang asing lagi bagi seorang guru. Baik guru di sekolah maupun guru di gereja. Peter Salim dan Yenni Salim mengatakan “ Mengajar adalah memberi pelajaran."[4] Lanjut Daniel Nuhamara mengatakan " Mengajar yang sesungguhnya adalah bagaikan penciptaan kondisi-kondisi yang memungkinkan orang lain belajar. "[5] Jadi mengajar adalah suatu kegiatan yang dilakukan oleh seorang guru dalam menyajikan materi atau bahan lingkungan yang kondusif untuk terjadinya proses belajar di dalam diri peserta didik.

Berdasarkan pengertian di atas dapat ditarik suatu kesimpulan bahwa metode mengajar adalah suatu cara yang ditempuh oleh seorang pengajar untuk menciptakan lingkungan yang kondusif sehingga peseta didik mampu memahami materi yang dipaparkan oleh guru. 


\section{Dasar Alkitabiah Metode Mengajar}

Penggunaan metode dalam mengajar bukanlah hal yang baru lagi. Baik dalam PL maupun PB banyak mengungkapkan bagaimana para nabi menyampaikan isi hati Tuhan dengan cara yang tepat agar mudah di pahami oleh umat.

Perjanjian Lama

Dalam Ul. 6:4-9 dan Bil. 15:37-41, berisikan pengakuan iman atau syewa, yang merupakan perintah dari Allah untuk diajarkan kepada umat Israel dengan tujuan agar mereka senantiasa mengingat dan melaksanakan dalam langkah kehidupan mereka. Ini merupakan suatu cara atau metode yang ditempuh agar umat tidak melupakan apa yang telah diperintahkan oleh Tuhan. Abraham adalah nenek moyang kaum Israel yang dalam pengajarannya bukan hanya melalui perkataan saja tetapi melalui tingkah lakunya yang menjadi teladan bagi umat. Dia memiliki integritas yang tinggi (Kejadian 22). Musa mendidik bangsa Israel di padang belantara dan mengatur pendidikan bagi mereka dengan jitu dan tepat agar supaya pengajaran agama yang memberi dasar seluruh kehidupan umat Tuhan itu akan dilanjutkan pula oleh penggantinya kemudian. Lanjut Neh. 8:9 berisi tentang pembacaan Torah yakni Taurat Tuhan yang dibacakan dengan jelas dan diberi keterangan-keterangan, sehingga pembacaan itu dapat dimengerti oleh umat yang mendengarkannya

Perjanjian Baru

Dasar Alkitab metode mengajar Dalam Perjanjian Baru dilakukan langsung oleh guru Agung Tuhan Yesus. Dia memakai banyak metode dalam pengajaran-Nya. Tuhan Yesus mengajar dengan penuh kuasa yang tidak dilakukan oleh ahli-ahli taurat (Mat 7:29), selain itu Dia mengajar 
dengan perumpamaan (Mar 4;Mat 13, 18) mengajar dengan konteks (Mat 21:18-22).

Rasul Paulus juga adalah seorang guru yang ulung, dia adalah tokoh penting di lapangan pendidikan agama. E.G Homrighausen dan I.H Enklaar mengatakan "Paulus sendiri di didik untuk menjadi seorang rabbi bagi bangsanya."[6] Paulus dalam mengajar selalu siap untuk bertukar pikiran, mengajar, menegur dan mengajak. Paulus mengajar di tempat-tempat ia menumpang di gedung-gedung yang disewanya, di lorong-lorong, di kota atau di padang. Rasul Paulus juga banyak mengajar melalui surat-surat

Jenis-jenis Metode Mengajar

Metode adalah bagian yang penting dalam mengajar, sebagai seorang guru, metode dapat mengekspresikan sikap dan keyakinannya. Dalam pemilihan dan penggunaan metode harus disesuaikan keadaan dan kondisi peserta didik. Mengingat begitu banyaknya jenis-jenis metode mengajar sehingga pada bagian ini penulis hanya akan membahas beberapa jenis-jenis metode yang dapat digunakan dalam mengajar. Adapun metode yang penulis paparkan adalah:

\section{Metode Diskusi}

Diskusi adalah sebuah interaksi komunikasi antara dua orang atau lebih/kelompok. Biasanya komunikasi antara mereka/kelompok tersebut berupa salah satu ilmu atau pengetahuan dasar yang akhirnya akan memberikan rasa pemahaman yang baik dan benar. Diskusi bisa berupa apa saja yang awalnya disebut topik. Dari topik inilah diskusi berkembang dan diperbincangkan yang pada akhirnya akan menghasilkan suatu pemahaman dari topik tersebut. Dalam teknik diskusi menuntut murid untuk selalu aktif sehingga suatu topik yang ditawarkan dapat terpecahkan dengan argumentasi dari setiap peserta. Syaiful Bahri Djamarah mengatakan bahwa, 
Teknik diskusi adalah salah satu teknik belajar mengajar yang dilakukan oleh seorang guru di sekolah, yang dimana di dalam teknik ini terjadi proses interaksi antara dua atau lebih individu yang terlibat, saling tukar menukar pengalaman, informasi, memecahkan masalah, dapat juga semuanya aktif tidak ada yang pasif sebagai pendengar. Tehnik diskusi merupakan suatu cara mengajar dengan cara memecahkan masalah yang dihadapi, baik dua orang atau lebih yang masing-masing mengajukan argumentasinya untuk memperkuat pendapatnya.[7]

Adapun tujuan dari teknik diskusi ini adalah untuk memotivasi murid untuk bisa memikirkan lebih dalam akan suatu topik yang didiskusikan. Tina Tuslina mengatakan bahwa Tujuan Tehnik Diskusi: untuk memotifasi dan memberi stimulasi kepada siswa agar berpikir dengan renungan yang dalam.[8]

Adapun penggunaan teknik diskusi dapat dilakukan dengan berbagai cara untuk memaksimalkan metode ini. Langkah-langkah penggunaan teknik ini menurut B.S. Sidjabat yaitu:

Pertama, tugas kelompok harus jelas yaitu berhubungan dengan apa peranan guru maupun peserta didik; apa yang dikerjakan dan bagaimana penilaiannya. Bila perlu guru dapat terlebih dahulu memberi penjelasan mengenai topik pembahasan serta berapa lama tiap pokok bahasan didiskusikan. Kelompok itu sendiri dapat menetapkan bagaimana cara kerja mereka, apakah terlebih dahulu masing-masing, kemudian berdua-dua, lalu masuk lagi ke dalam kelompok serta mengadakan acara pleno bersama dari semua anggota kelompok. Janganlah guru lupa bahwa sering dalam pleno itu acara tanya jawab juga dapat terjadi.

Kedua, guru perlu terus memahami bagaimana cara memelihara kelompok agar mengalami dan meningkatkan suasana bersahabat serta mendorong.[9]

Metode Kerja Kelompok

Teknik kerja kelompok adalalah suatu cara mengajar, di mana siswa di dalam kelas dipandang sebagai suatu kelompok atau dibagi menjadi beberapa kelompok. Mereka bekerja bersama dalam memecahkan masalah, 
atau melaksanakan tugas tertentu, dan berusaha mencapai tujuan pengajaran yang telah ditentukan oleh guru. Teknik ini dilakukan dengan membagi kelompok yang terdiri dari 3-6 orang atau disesuaikan dengan jumlah murid yang ada di dalam kelas. Dalam teknik ini guru mempersiapkan topik, mempersiapkan sarana dan memotivasi setiap kelompok. Paulus Lilik Kristianto mengatakan:

Garis besar metode kelompok kerja yaitu 1) mempersiapkan topik khusus yang sama atau berbeda untuk setiap kelompok; 2) mempersiapkan kertas kerja dan tempat yang cukup untuk membuat ringkasan; 3) memilih seorang pemimpin untuk setiap kelompok atau menjelaskan bagaimana suatu kelompok memilih pemimpin; 4) guru mengunjungi setiap kelompok untuk mendorong dan membantu; 5) mereka masuk dalam kelompok besar atau berkumpul kembali. Secara bersama-sama setiap kelompok berdiskusi untuk mencari jalan keluar sedangkan guru meringkas."[10]

Tehnik kerja kelompok ini dapat mendorong peserta didik untuk berinteraksi dalam kelompok kecil, menuangkan ide-ide atau pengetahuan baru, menjangkau peserta didik untuk tertarik dan berpartisipasi secara aktif dalam kelompok. Tina Tuslina mengatakan bahwa keuntungan teknik kerja kelompok adalah:

- $\quad$ Agar siswa lebih aktif tergabung dalam pelajaran mereka

- $\quad$ Agar guru dapat lebih memperhatikan kemampuan siswa

- Agar para siswa bisa menggunakan ketrampilan bertanya dalam membahas suatu masalah

Dapat mengembangkan bakat kepemimpinan para siswa serta mengerjakan ketrampilan berdiskusi[11]

Melalui kelompok yang ada peserta didik akan mengembangkan pengetahuannya bukan hanya menerima sajian materi yang disiapkan guru.

Metode Menghafal

Setiap orang dapat meningkatkan kemampuannya dalam mengingat, Harianto mengatakan, "Proses mengingat atau menghafal terdiri dari tiga 
tahap yaitu memperoleh bahan yang akan diingat, menyimpan bahan dalam ingatan dan mengeluarkan bahan dari ingatan."[12] Lanjut E.G Homrighausen dan I.H Enklaar mengatakan, " Cara ini berfaedah dan perlu dipakai...memang ada berbagai-bagai hal yang harus dihafal murid-murid kita sebab harus selalu diingat dan diketahui."[13] Teknik dari menghafal tidak memerlukan banyak penalaran tetapi cukup mengulangi bahan yang disajikan untuk dihafal.

Langkah-langkah dalam menggunakan metode ini dapat dilakukan dalam beberapa cara. E.G. Homrighausen menjelaskan bahwa, “.... muridmurid kita mengulangi secara otomatis saja apa yang telah kita suruh mereka pelajari. Memang ada berbagai-bagai hal yang harus dihafal murid-murid kita, sebab harus selalu diingat dan diketahui: doa-doa, nas-nas penting dalam Alkitab, daftar isi Kitab Suci, nyanyian gereja, dan lain-lainnya." [14]

\section{Metode Demonstrasi}

Tehnik demonstrasi merupakan tehnik mengajar dimana seorang instruktur atau tim guru menunjukkan, memperlihatkan suatu proses. Teknik Penggunaan Metode demonstrasi dilakukan dengan menunjukkan benda baik yang sebenarnya, model, maupun tiruannya dan disertai dengan penjelasan lisan. Wina Sanjaya mengemukakan bahwa bahasa demonstrasi adalah cara penyajian pelajaran dengan memperagakan dan mempertunjukkan kepada siswa tentang suatu proses, situasi atau benda tertentu yang sedang dipelajari baik dalam bentuk sebenarnya maupun dalam bentuk tiruan yang dipertunjukkan oleh guru atau sumber belajar lain ahli dalam topik bahasan yang harus didemonstrasikan.[15]

Teknik Demonstrasi biasanya berkenaan dengan tindakan-tindakan atau prosedur yang dilakukan, misalnya: proses mengerjakan sesuatu, membandingkan suatu cara dengan cara lain, untuk mengetahui melihat kebenaran sesuatu. Dengan metode demonstrasi peserta didik 
berkesempatan mengembangkan kemampuan mengamati segala benda yang sedang terlibat dalam proses, serta dapat mengambil kesimpulan-kesimpulan yang diharapkan.

\section{Metode Ceramah}

Teknik ceramah ialah cara mengajar yang paling tradisional dan telah lama dijalankan dalam sejarah pendidikan, yaitu dimana seorang guru menularkan pengetahuannya kepada siswa secara lisan atau ceramah.

Dalam teknik ceramah dilakukan dengan memberikan uraian atau penjelasan kepada sejumlah murid pada waktu dan tempat tertentu. Dengan kata lain tehnik ini adalah sebuah tehnik mengajar dengan menyampaikan informasi dan pengetahuan secara lisan kepada sejumlah siswa yang pada umumnya me carngikuti secara pasif. Tehnik ini disebut juga dengan tehnik kuliah atau tehnik pidato. Syaiful Bahri Djamarah mengatakan bahwa cara mengajar dengan ceramah dapat dikatakan sebagai teknik kuliah, merupakan suatu cara mengajar yang digunakan untuk menyampaikan keterangan atau informasi atau uraian tentang suatu pokok persoalan serta masalah secara lisan." [16]

Adapun dalam teknik penggunaan metode ceramah adalah ketika memberi ceramah, guru harus menghindari perkataan yang bertele-tele. Dia harus mengubah-ubah caranya, berbicara dengan jelas, memakai bahasa para pendengarnya, dan membawa para pelajar untuk menyadari dan memecahkan masalah. Dia harus juga menyisipkan lukisan-lukisan dan contoh-contoh yang baik, sering kali memakai humor dan memperhatikan reaksi pendengarnya.[17]

Metode Role Play (Bermain Peran)

Teknik ini disebut juga dengan sosio drama, teknik ini dilakukan dengan cara murid diajak untuk memahami peranan, sikap, tingkah laku, 
dan nilai dengan melihat dari sudut pandang berbeda dengan melakoni tokoh tertentu. Adapun tata cara penggunaan teknik ini seperti yang dikatakan Syaiul Bahri Jamarah adalah:

a).Tetapkan dahulu masalah-masalah sosial yang menarik perhatian siswa untuk dibahas. b.) ceritakan kepada siswa mengenai isi dari masalah -masalahdalam konteks cerita tersebut. c.) tetapkan siswa yang dapat atau yang bersedia untuk memainkan peranannya di depan kelas. d.) jelaskan kepada pendengar mengenai peranan mereka pada waktu sosiodrama sedang berlangsung. e.) beri kesempatan kepada para pelaku untuk berunding beberapa menit sebelum mereka memainkan peranannya. f.) akhiri sosiodrama pada waktu situasi pembicaraan mencapai ketegangan. g.) akhiri sosiodrama dengan diskusi kelas untuk bersama-sama memecahkan masalah persoalan yang ada pada sosiodrama tersebut. h.) jangan lupa menilai hasil sosiodrama tersebut sebagai bahan pertimbangan lebih lanjut.

Dengan bermain peran diharapkan murid terampil atau menghayati dan berperan dalam berbagai figur khayalan atau figur sesungguhnya dalam berbagai situasi. Dalam teknik ini tidak menekankan pada aspek kemampuan siswa dalam melakoni peran suatu tokoh melainkan lebih kepada masalah yang diangkat dalam pertunjukan.

[1] Peter Salim dan Yenni Salim, Kamus Besar Bahasa Indonesia Kontemporer (Modern English: Jakarta, 1995), s.v. "metode".

[2]Daniel Nuhamara, Pembimbing PAK, (Jabar: Jurnal Info Media 2009), 133.

[3]E. G Homrighausen dan I.H Enklaar, Pendidikan Agama

Kristen (BPK Gunung Mulia: Jakarta 1993), 88.

[4] Ibid, s.v "mengajar"

[5] Ibid

[6]Ibid, 18.

[7] Syaiful Bahri Djamarah, Starategi Belajar Mengajar, ${ }_{,}$(Jakarta: Rineka Cipta,2006),87

[8] http:/ tinatuslina.blogspot.com/2012/03/macam-macam-tehnikpenyajian-dalam.html 
[9]B.S. Sidjabat, Menjadi Guru Profesional (Bandung: Kalam Hidup, 2004),98-99.

[10] Paulus Lilik Kristianto, Prinsip dan Praktik Pendidikan Agama Kristen (Yogyakarta: Yayasan ANDI, 2006), 84.

[11] Tina Tuslina, Op-cit

[12]Harianto, Pendiidkan Agama Kristen dalam Alkitab dan dunia pendidikan masa Kini (Yogyakarta:Yayasan ANDI, 2012), 168

[13] Ibid. 99

[14]E.G. Homrighausen, Pendidikan Agama kristen (Jakarta: BPK Gunung Mulia, 2008), 83.

[15] Wina Sanjaya, Strategi Pembelajaran. (Jakarta: Kencana Prenada Media,2006), 91

[16] Syaiful Bahri Djamarah, Op.Cit, 97

[17] Paul E. Loth, Teknik Mengajar, (Malang: Gandum Mas, 1986), 29 [18]Ibid, 89.

\section{DAFTAR PUSTAKA}

Alexander, Ferdinant, and Fenni Regina Pono. "Penerapan Metode Pembelajaran Kooperatif Tipe Examples Non Examples Untuk Meningkatkan Hasil Belajar Kognitif Siswa." Jurnal Ilmiah Religiosity Entity Humanity (JIREH) 1, no. 2 (December 23, 2019): 110-26. https://doi.org/10.37364/jireh.v1i2.21.

Djamarah Syaiful Bahri. Starategi Belajar Mengajar. Jakarta: Rineka Cipta,2006.

Harianto, Pendiidkan Agama Kristen dalam Alkitab dan dunia pendidikan masa Kini. Yogyakarta:Yayasan ANDI, 2012.

Homrighausen, E. G dan I.H Enklaar, Pendidikan Agama Kristen. BPK Gunung Mulia: Jakarta 1993.

. Pendidikan Agama Kristen. Jakarta: BPK Gunung Mulia, 2008. Kristianto, Paulus Lilik. Prinsip dan Praktik Pendidikan Agama Kristen. Yogyakarta: Yayasan ANDI, 2006.

Loth, Paul E. Teknik Mengajar. Malang: Gandum Mas, 1986.

Nuhamara, Daniel Pembimbing PAK. Jabar: Jurnal Info Media 2009.

Salim, Peter dan Yenni Salim, Kamus Besar Bahasa Indonesia Kontemporer. Modern English: Jakarta, 1995.

Sidjabat, _B.S. Menjadi Guru Profesional. Bandung: Kalam Hidup, 2004. 
Rantesalu, Marsi Bombongan. "GURU PENDIDIKAN AGAMA KRISTEN SEBAGAI PELOPOR REVOLUSI MENTAL." Preprint. AgriXiv, October 14, 2019. https://doi.org/10.31220/osf.io/576qt.

Rantesalu, Marsi Bombongan, and Syani Bombongan Rante Salu. "PERANAN AGAMA KRISTEN DALAM MENGHADAPI KONFLIK AGAMA DI INDONESIA." Preprint. AgriXiv, October 14, 2019. https://doi.org/10.31220/osf.io/p6bh7.

Wina Sanjaya, Strategi Pembelajaran. Jakarta: Kencana Prenada Media,2006. http://tinatuslina.blogspot.com/2012/03/macam-macam-tehnik-penyajiandalam.html 